\title{
Smallholder willingness to pay and preferences in the way irrigation water should be managed: a choice experiment application in KwaZulu-Natal, South Africa
}

\author{
U Chipfupa' and E Wale ${ }^{1}$ \\ 'School of Agricultural, Earth and Environmental Sciences, University of KwaZulu-Natal, Private Bag X01, Scottsville 3209, Pietermaritzburg, South Africa
}

\begin{abstract}
Efficient and sustainable utilization of irrigation water is the key to realizing the objective of enhancing agricultural productivity and commercializing smallholder irrigation farming. Valuing and recognizing the scarcity of irrigation water is essential for its sustainable use. Using cross-sectional data from 328 smallholders in and around Makhathini and Ndumo-B irrigation schemes in KwaZulu-Natal Province, the study aimed to assess smallholder farmers' preferences for the way irrigation water resources should be managed and their willingness to pay for irrigation water. This was done employing a choice experiment method. The results suggest the need for irrigation water pricing to reflect irrigation intensity. They also show that improving agricultural production and productivity, with market access can enhance farmers' willingness and ability to pay for irrigation water. The need to consider multiple uses of irrigation water for sustainable utilization of water resources is evident, while supporting women smallholders will have a positive impact on their willingness to pay for irrigation water. The paper recommends a shift towards on-farm volumetric water pricing in the irrigation schemes. The schemes should also have clearly defined boundaries and enforceable rules on collective use of water. The design of irrigation infrastructure should integrate other uses of irrigation water such as domestic and livestock purposes. Consequently, there is a need for further research to ensure that irrigation water prices reflect the marginal value of irrigation water use. Policies should address factors that inherently result in gender differences in terms of access to productive resources which negatively affect sustainable water utilization.
\end{abstract}

Keywords: water valuation, farmers' willingness to pay for irrigation water, water pricing, farmers' preference on irrigation water management, multiple uses of irrigation water

\section{INTRODUCTION}

Efficient utilization of water should underpin efforts towards commercializing agricultural production in smallholder irrigation. Globally, irrigated agriculture uses nearly $70 \%$ of freshwater withdrawn from rivers and aquifers, and the figure is even higher for sub-Saharan Africa (87\%) (FAO, 2011). The improved performance of irrigation systems compared to rainfed agriculture has triggered the expansion of irrigation farming. Consequently, this has increased the demand for water, adding to the growing concerns of water scarcity, amid other competing water uses. South Africa is one of the waterscarce countries in Africa. The average annual rainfall in the country is approximately $500 \mathrm{~mm}$ compared to a global average of $860 \mathrm{~mm}$ (Speelman et al., 2011; Schreiner, 2015). Kruger and Nxumalo (2017) also showed some large variations in the rainfall distribution in the country, with observed increases in the south and decreases in the northern and north-eastern parts over the period 1921-2015. There are concerns that by 2030 available water in the country's catchments will not be enough to meet the national water requirements (Schur, 2000). Hence, the need to promote sustainable and efficient utilization of the available water resources, failure of which could have dire consequences for smallholder livelihoods, rural employment and poverty reduction.

Schur (2000) identifies economic incentives as vital tools to improve the allocation of water resources. If a resource, such as irrigation water, is scarce, its scarcity must be reflected in the market thereby inducing the incentive to use it more

${ }^{\star}$ Corresponding author, email: uchipfupa@gmail.com Received 11 October 2017; accepted in revised form 13 June 2019 efficiently and sustainably (Ray, 2011). Increasingly, research has been focusing on finding ways and means of improving efficiency in the irrigated agriculture sector to increase water supply for other uses (Reinders et al., 2013). The challenge is that the current water management arrangements in most smallholder irrigation schemes in South Africa provide no incentive for sustainable utilization of water, maintenance of irrigation infrastructure and collective management of the schemes (Muchara et al., 2014). The scheme-level institutional failures, the poverty of irrigation infrastructure and the nonavailability of agricultural water markets means irrigation water is often considered as a common pool resource (nonexcludable, but rival in consumption) (Barton and Bergland, 2010; Muchara et al., 2016). This makes it difficult to monitor water consumption in the irrigation schemes or even charge volumetrically. Coupled with poor record-keeping and lack of water measurement devices in most schemes, precision in irrigation water valuation is close to impossible (Lange and Hassan, 2007; Young and Loomis, 2014; Muchara et al., 2016). In the absence of credible water value estimates, there would be little or no incentive for changing irrigation practices and efficient utilization of water. This study argues that until the commitments to gradually phase in the full cost of providing irrigation water are met, the current irrigation water charges will have minimal impact on smallholder irrigation practices.

Several approaches have been employed in the past to determine the economic value of irrigation water and inform water pricing and management policies. These are categorised as direct (stated preference) and indirect (revealed preference) methods. Direct techniques, such as contingent valuation (CV) and choice experiment modelling (CEM), obtain preferences directly through questioning individuals on their 
willingness to pay (WTP) for a good or a service. Indirect techniques depend on observed market behaviour and data to infer an economic value of water (e.g., residual valuation, hedonic pricing, production function, and demand function approaches) (Young and Loomis, 2014). The commonly applied approach to irrigation water valuation in South Africa is the residual valuation method (e.g. Speelman et al., 2011; Muchara et al., 2016; Njoko and Mudhara, 2017). However, the use of this or any other revealed preference method is problematic because markets for some key inputs in smallholder agriculture (such as land) are non-existent. In such cases, it is recommended to use the stated preference approaches, i.e., the CV or CEM (e.g. Kunimitsu, 2009; and Bhaduri and Kloos, 2013). However, comparing these two, the CEM is more suitable to valuation of irrigation water in the context of smallholder farmers for the following reasons: The approach can model heterogenous preferences in irrigation water services among smallholder farmers which results in higher water use efficiency (Abu-Zeid, 2001). The CEM also often requires a small sample of data to achieve similar accuracy in water valuation estimates (Barton and Taron, 2010). This is especially important given the high cost of data collection in Africa. The CEM is also not affected by some common biases associated with the 'warm glow' effect (deriving moral satisfaction from doing something deemed socially right) and strategic positioning by respondents often encountered in CV (Birol et al., 2006).

The application of the CEM is relatively new to irrigation water valuation with just a few studies conducted so far (e.g. Kunimitsu, 2009; Barton and Bergland, 2010; Bhaduri and Kloos, 2013). Most of the studies are from Asia and there is a gap in the literature regarding Africa's smallholder irrigation sector. To the best of the authors' knowledge CEM has not been applied to irrigation water valuation in the context of South Africa. However, the method has been widely used in other sectors in the country to determine non-market values for different environmental goods (e.g. Jaeck and Lifran, 2009), municipal water (e.g. Kanyoka et al., 2008) and technology adoption (e.g. Asrat et al., 2010), among others. Therefore, this study aimed to use the CEM to assess farmers' preferences on how irrigation water should be managed and determine their willingness to pay (WTP) for the resource. The farmers' preferences are assessed from three angles, i.e., water management, multiple uses of water, and multiple cropping. These represent the institutional arrangements in irrigation water management, other possible uses of irrigation water and the demand for irrigation water, respectively. The study contributes to the literature on water pricing in smallholder irrigation. The findings can be used to inform irrigation water management and water pricing policies for resource-poor farmers, contributing to sustainable and efficient utilisation of irrigation water resources.

\section{RESEARCH METHODOLOGY}

\section{The South African context}

Agricultural water in most smallholder irrigation schemes in South Africa is provided as a free commodity, subsidized exclusively by the government (Muchara et al., 2014). Schreiner (2015) reports that the country is currently providing a subsidy of over US $\$ 30$ million per year to the irrigation sector. The 'Draft Pricing Strategy for Water Use Charges' drawn in terms of the National Water Act of 1998 (RSA, 1998) gives provisions for subsidized water pricing rates, including operations and maintenance charges, for irrigation schemes benefiting resource-poor communities (DWS, 2015). The policy states that farmers in such communities incur no charge for the initial 5 years, and after that the water charges are phased in for the next 5 years at a rate of $20 \%$ per annum. The pricing strategy attempts to balance economic efficiency and the social equity side of irrigation water provision. However, this has created perceptions that water is a free good and situations where smallholder irrigation schemes are dependent on the government for operation and maintenance costs (Backeberg, 2006).

\section{Study area}

The study was conducted in two areas in Jozini, a local municipality in uMkhanyakhude District in the northern part of KwaZulu-Natal Province, South Africa (Fig. 1). Jozini covers $3057 \mathrm{~km}^{2}$ of land and borders Mozambique to the north, eSwatini to the west and four other local municipalities to the east and south. It is predominately rural but has 4 semiformalized towns that act as tertiary centres. The municipality has a population size of 186502 which is largely youthful ( $72 \%$ below 29 years) and mostly female (54\%). Education levels are low (13.5\% have no schooling, $2 \%$ have a post-Grade 12 qualification) and this is reflected in the high poverty levels ( $43 \%$ of households reporting no income in the last census) (Jozini Local Municipality, 2015).

According to the Jozini Municipality, agriculture forms one of the major important sectors within the municipality (Jozini Local Municipality, 2015). The general livelihoods resemble a mixed farming system with farmers engaged in either crop farming (rainfed and irrigated) or livestock production or both. Due to persistent droughts, irrigation farming has assumed greater importance. Irrigation is conducted both in

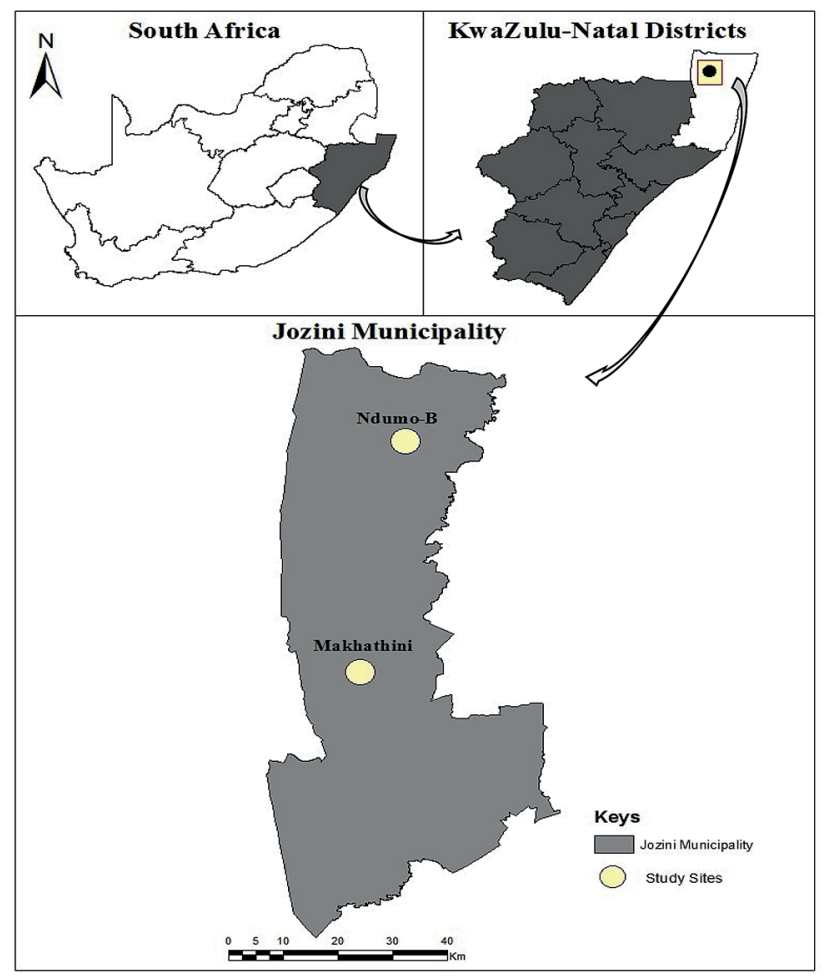

Figure 1. Location of the study area 
schemes and outside. Land (in scheme or outside) is held on a permission to occupy (only use rights) basis granted by the traditional authorities. The land holding of the study sample ranges from as little as 0.2 ha to 10 ha of land. Those who irrigate outside the schemes include independent irrigators, homestead gardeners and community gardeners.

Scheme irrigation is mainly through two major schemes: i.e., Makhathini and Ndumo-B. These are approximately 80 $\mathrm{km}$ apart. Makhathini irrigation scheme covers an estimated 4500 ha of irrigated land and has a total of 1167 smallholders farming as individuals or part of cooperatives. It is managed by Mjindi Farming Private Limited, a state-owned entity. The scheme is serviced by a $34 \mathrm{~km}$ canal which carries water from the Jozini Dam, drawn by 6 pump stations. Ndumo-B irrigation scheme is relatively small and covers 500 ha of land. It is managed and operated by two cooperatives. At the time of the survey, only a part of the scheme with 21 members was operational (200 ha). Water is drawn from the Pongola River using an electric pump and brought to the plots using pipes. In both schemes, there is currently no volumetric water charging system at the farmer level.

\section{The design of the choice experiment}

Three critical steps are followed when designing a choice experiment, namely, the establishment of attributes of interest, assigning levels and, finally, the design of the choice sets (Mangham et al., 2009; Johnson et al., 2013). How each step is conducted has implications for the validity and credibility of the results. In this study, complementary processes were followed to identify and assign levels to attributes of irrigation water in the target communities. The processes include literature review (including policy documents), in-depth discussions with farmers, field observations and key informant interviews with relevant stakeholders. For selection, an attribute had to be relevant to the agricultural policy direction in South Africa, hold significant value to the smallholders in relation to the payment of water and have literature which supports its importance. This process resulted in 4 attributes (Table 1).

The attribute 'membership to an organization governing water use' represents institutional arrangements in the irrigation schemes and knowledge on collective water management. Water governance and management of irrigation schemes are key aspects of sustainable management and success of smallholder irrigation in South Africa (Muchara et al., 2014). Currently, water management is implemented through cooperatives or a third-party institution managing the irrigation schemes on behalf of farmers. According to the National Water Act of 1998 (RSA, 1998), the water allocation rights are obtainable by any individual or organization drawing water from a surface or groundwater resource. However, resource-poor farmers are encouraged to form cooperatives, to assist them not only in water management but also in access to information, finance and high-value markets.

The attribute 'multiple uses of irrigation water' represents the possibility of using irrigation water for uses other than irrigation. The lack of consideration of the different uses of irrigation water results in undervaluation and inefficient allocation of the resource (Meinzen-Dick and Van Der Hoek, 2001). The current water pricing policy (see DWS, 2015) does not consider these other different dimensions in irrigation water valuation. Currently, $20 \%$ of the sampled smallholders use irrigation water solely for irrigation purposes while the remaining majority also use it for other purposes (watering of livestock and/or domestic use). Though not desirable, since access to water is at least in theory considered a human right, authorities indicate that it is possible to fence off the canal or use a pipe system that prevents access outside of the schemes.

The attribute 'number of crops per season' characterizes the demand for irrigation water by each farmer, i.e., irrigation intensity. Farmers growing more crops (multiple crops or more quantities of the same crop) are more likely to use more water per season, yet they pay the same amount of annual water fees per hectare. Currently, some scheme irrigators have voiced their concerns with the non-volumetric charging system and believe that even in the absence of water meters, those growing more crops should pay more for water.

The attribute 'annual payment for irrigation water per ha (water fees)' includes both raw water fees and water service charges (electricity and maintenance) paid by smallholders to access irrigation water. Raw irrigation water is subsidized, with farmers paying minimal fees or nothing at all. However, to some extent, they contribute to the maintenance of water

Table 1. Attributes for the choice experiment*

\begin{tabular}{llc}
\hline Attribute & Level & $\begin{array}{c}\text { Expected impact } \\
\text { on choice }\end{array}$ \\
\hline Membership to an organization governing water use & Yes & + \\
Multiple uses of irrigation water & No (status quo) & + \\
& Irrigation only (status quo) & Irrigation and domestic use \\
Number of crops per season & Irrigation and livestock & + \\
& Irrigation, domestic and livestock use & \\
Annual payment for irrigation water (water fees) (ZAR.ha $\left.{ }^{-1}\right)$ & 2 crop per season (status quo) & - \\
& 2 crops per season & \\
& 4000 & \\
& 5000 &
\end{tabular}

${ }^{*} A$ combination of the attribute levels with status quo in parentheses represents the current scenario used in the study. It is assumed that in the absence of institutional challenges farmers in both schemes will face the same water charges. In the absence of any other information, the same status quo is also used for out-of-scheme farmers. 
infrastructure and pumping charges. Those from Makhathini irrigation scheme currently pay a subsidized charge of approximately $2500 \mathrm{ZAR} \cdot \mathrm{ha}^{-1} \cdot \mathrm{yr}^{-1}$. The charge includes raw water and other related services (electricity and water infrastructure maintenance). Smallholders from Ndumo-B irrigation scheme pay almost 3 times more (7 $\left.200 \mathrm{ZAR} \mathrm{ha}^{-1} \cdot \mathrm{yr}^{-1}\right)$ since they cater for the full cost of water provision. Though they have no charge for raw water, their electricity bill translates to an average of approximately $600 \mathrm{ZAR} \cdot \mathrm{ha}^{-1} \cdot \mathrm{yr}^{-1}$.

In designing the choice sets, the study aimed to achieve a balance between statistical efficiency of the design and response efficiency. Statistical efficiency refers to 'minimizing the confidence intervals around parameter estimates in a choice model' while response efficiency deals with the 'measurement error resulting from respondents' inattention to the choice questions or other unobserved, contextual influences' (Johnson et al., 2013 p. 6). Response efficiency could also be the result of respondent's failure to comprehend all the choice sets. Statistically efficient designs are orthogonal (levels of each attribute are statistically independent of each other), balanced (each attribute level appears in equal proportion across choices) and minimize overlap (repeating of the attribute level with a choice set) (Ryan et al., 2012). Due to the practical impossibility of presenting the full set of choices $\left(128\left(2 \times 4^{3}\right)\right)$, a fractional factorial design was adopted in the study (Kuhfeld, 2010). The orthogonal design option in SPSS $v 24$ was used to generate a choice set of 16 alternatives. Pairwise correlation coefficients of the attributes showed that the choice set met the orthogonality criterion while the level of balance was achieved. To increase response efficiency, a compromise was made on the minimum overlap condition. Johnson et al. (2013) state that overlap improves response efficiency by reducing the cognitive burden of evaluating huge attribute differences in a choice set. However, this was kept to a minimum to limit the negative impact on the design efficiency. Of the 16 alternatives, one was similar to the status quo scenario and hence was dropped from the list. The remaining list of 15 alternatives was divided into 5 choice sets of 4 alternatives, including the opt-out choice. Pretesting results showed that smallholders could respond to these with minimum difficulties in understanding or before boredom sets in. Literature suggests a practical limit of 18 choice sets of 2 options that an individual can respond to with no difficulties (Mangham et al., 2009).

\section{Sampling and data collection}

The study targeted smallholders in and around the two irrigation schemes. This was done because the schemes also benefit other farmers outside the schemes. Moreover, it is important to align the study with the South African Government's objective of irrigation expansion. A total of 328 smallholder farmers were interviewed. The sample was stratified to include scheme irrigators $(n=109)$, non-scheme irrigators $(n=174)$ and dryland farmers $(n=45)$. Dryland farmers are those currently practicing rainfed farming. The study targeted at least $10 \%$ of scheme farmers actively engaged in farming at the time of conducting the study. Owing to their homogeneity, simple random sampling was used to identify the scheme irrigators using a list obtained from the scheme management and cooperatives. The other types of farmers were identified through snowball sampling since there was no available information regarding their populations. However, this was done proportionally considering the critical mass in each area. The choice experiment was conducted in a once-off survey in April 2016 through a questionnaire administered by 6 well-trained enumerators over a 7-day period. Besides the choice experiment questions, the questionnaire also covered information on the demographic and socioeconomic status of the farm households. To check the cognitive ability of the farmers in comprehending and responding to the proposed choice sets, a pre-testing exercise was conducted. Issues from the pre-test were addressed and changes made to the questionnaire before the actual survey.

\section{Empirical approach}

The theoretical foundation for choice modelling, the random utility model, is used to analyse the farmer's utility maximization problem (McFadden, 1973). It is founded on Lancaster's characteristics theory which indicates that it is not

Table 2. Example of a choice set in the study

\begin{tabular}{|c|c|c|c|c|c|}
\hline \multicolumn{2}{|r|}{ Attributes } & \multirow{2}{*}{$\begin{array}{l}\text { Option } 1 \\
\text { No }\end{array}$} & \multirow{2}{*}{$\begin{array}{l}\text { Option } 2 \\
\text { No }\end{array}$} & \multirow{2}{*}{$\begin{array}{l}\text { Option } 3 \\
\text { Yes }\end{array}$} & \multirow{2}{*}{$\begin{array}{l}\text { Status quo } \\
\text { No }\end{array}$} \\
\hline & $\begin{array}{l}\text { Membership to a water } \\
\text { organization }\end{array}$ & & & & \\
\hline & Multiple uses of water & Irrigation only & $\begin{array}{l}\text { Irrigation, domestic } \\
\text { and livestock }\end{array}$ & $\begin{array}{l}\text { Irrigation and } \\
\text { domestic use }\end{array}$ & Irrigation only \\
\hline & $\begin{array}{l}\text { Number of crops per } \\
\text { season }\end{array}$ & $\begin{array}{l}\text { Three crops per } \\
\text { season }\end{array}$ & Two crops per season & $\begin{array}{l}\text { At least } 4 \text { crops per } \\
\text { season }\end{array}$ & $\begin{array}{l}\text { One crop per } \\
\text { season }\end{array}$ \\
\hline & $\begin{array}{l}\text { Annual payment of } \\
\text { water (Water fees) } \\
\left(\text { ZAR } h a^{-1}\right)\end{array}$ & 7000 & 3000 & 2500 & 2500 \\
\hline
\end{tabular}

Please tick only one 
the good but the attributes it possesses that determines its value to a consumer (Lancaster, 1966). The decision maker is the only one with knowledge of this utility. What the researcher observes are the different levels of the attributes and not the utility of the decision maker (Train, 2009). The study assumes that smallholders are rational in their decisions, and their WTP for irrigation water is determined by the utility they derive from the use of that water. The utility depends on their preferences for the various factors which impact on irrigation water use. At any one time, given a set of alternatives, rational farmers choose an alternative that gives them the highest utility.

To illustrate this, if a farmer's utility depends on a choice made from a given choice set $(J)$ of irrigation water use options, the utility function for the farmer is given by:

$$
U_{i j}=V_{i j}+\varepsilon_{i j} \quad j=1,2, \ldots \ldots, J
$$

where, for any farmer $i$, a given level of utility $U$ is associated with alternative choice $j$. The utility function for each farmer has 2 parts, i.e., an observable part $(V)$ as well and an unobservable part $(\varepsilon) . V$ is assumed to be a linear function of the attributes and any socio-economic characteristics of the farmer such as income and resource endowment. The exact estimation of the model depends on the assumptions made about the probability distribution of $\varepsilon_{i j}$. If $\varepsilon_{i j}$ is independent and identically distributed with extreme value distribution, one should estimate the conditional logit model (Greene, 2012). In this model, the probability of individual farmer $i$ choosing alternative $j$ can then be expressed as:

$$
P_{i j}=\frac{\exp \left(V_{i j}\right)}{\sum_{j=1}^{J} \exp \left(V_{i j}\right)}=\frac{\exp \left(\beta^{\prime} X_{i j}\right)}{\sum_{j=1}^{J} \exp \left(\beta^{\prime} X_{i j}\right)}
$$

where $X_{i j}$ are all the observed factors and $\beta$ represents parameters estimated from the model. If there are $m$ attributes, $V_{i j}$ is expressed as:

$$
V_{i j}=\beta_{0} A S C+\beta_{1} X_{1 j}+\beta_{2} X_{2 j}+\beta_{m} X_{m j}
$$

where $\beta_{m}$ is the coefficient of attribute $X_{m}$. The status quo or current situation is represented by ASC which is a dummy variable with $1=$ choice of current status and $0=$ any other alternative. The inclusion of the status quo provides an opt-out choice for those farmers not interested in any of the suggested alternatives.

However, if the error terms are correlated and not identically distributed, the independence from irrelevant alternatives (IIA) assumption of the conditional logit model is violated (Hausman and McFadden, 1984). The likelihood of this happening is high in the presence of heterogeneity in farmer preferences and socioeconomic factors. In such situations, estimating the conditional logit would result in biased estimates. The recommendation is to use the mixed logit, a less restrictive model that allows random taste variation and correlation in the error terms (Train, 2009; Greene, 2012).

In the mixed logit model, the probability $P$ of individual farmer $i$ choosing alternative $j$ then becomes:

$$
P_{i j}=\int\left(\frac{\exp \left(\beta^{\prime} X_{i j}\right)}{\sum_{j=1}^{J} \exp \left(\beta^{\prime} X_{i j}\right)}\right) f(\beta) d \beta
$$

where $f(\beta)$ is the distribution function for $\beta$ and $X_{i j}$ is a vector of observed variables. Three interaction terms were introduced in the model to test several assumptions regarding WTP for irrigation water, i.e., the effect of gender and crop income on the cost of irrigation water and the effect of livestock ownership on the multiple uses of irrigation water. In the estimation of the mixed logit, the non-price attributes were randomized while the cost attribute was treated as non-random (Layton, 2000; Lee et al., 2014), a preferred option because it allowed the distribution of the WTP to be the same as that of the attribute (Scarpa et al., 2008), making it easier to compute WTP estimates.

\section{Willingness to pay estimation}

Since the cost attribute (water fees) is taken as non-random, the WTP distribution takes the same form as that of the non-price attributes. According to Scarpa et al. (2008), the mean and standard deviation of the WTP can thus be given by the mean and standard deviation of the attribute scaled by the inverse of the price coefficient. For a given attribute, the ratio of the attribute to the price coefficient also represents the marginal WTP for a change in the attribute values (Lee et al., 2014). Following Bech and Gyrd-Hansen (2005), the coefficient of the dummy attributes' in the equation, e.g. 'multiple uses of irrigation water', is multiplied by two. The equation is slightly adjusted to incorporate the interaction effects associated with the price or non-price attributes (Giergiczny et al., 2012; Bhaduri and Kloos, 2013). For example, computing the WTP for the attribute 'multiple uses of irrigation water' should include 2 terms in the numerator, i.e., 'multiple uses' and 'multiple uses $\times$ no_cattle'. The denominator, which will be the same for all attributes, should include 3 terms, i.e., 'water fees', 'water fees $\times$ gender' and 'water fees $\times$ crop_income'.

$$
W T P_{\text {multiple_uses }}=-\frac{2 \beta_{\text {multiple_uses }}+\beta_{\text {multiple_uses } x \text { no_cattle }}}{\beta_{\text {fee }}+\beta_{\text {fees } x \text { gender }}+\beta_{\text {fees } x \text { crp_income }}}
$$

\section{RESULTS AND DISCUSSION}

\section{The comparative descriptive results}

Table 3 shows the characteristics of the respondents in respect of the demographics and other variables related to the attributes used in the choice experiment. Comparison by farmer category shows statistically significant differences in the number of crops grown per season, cattle ownership, multiple uses of irrigation water and interest in collective water management. Non-scheme irrigators grow more crops per season while rainfed farmers own approximately 3 times the number of cattle compared to the other farmers. Evidence of multiple uses of irrigation water is higher among farmers outside compared to those in the schemes. Interest in collective water management is also higher among farmers outside of the schemes compared to those inside. This is because smallholder farmers in the schemes have negative experiences with collective water management. Non-compliance by some members result in consequences that affect even those who are compliant. For example, the failure by some to pay for water use charges often leads to the disconnection of electricity or water which affects everyone.

Regarding differences across the study areas (Makhathini and Ndumo-B), statistically significant differences are observed in gender, the number of crops grown per season, crop income, membership to cooperatives and multiple uses of water. Makhathini had more female respondents and a higher 
proportion of farmers in cooperative membership compared to Ndumo-B. However, Ndumo-B farmers grow, on average, more crops per season and obtain approximately 4 times the crop income of Makhathini farmers. Furthermore, Ndumo-B has a higher proportion of farmers who use irrigation water for other purposes.

\section{The results of the choice experiment}

The study estimates the empirical models using a dataset of 6450 ( $327 \times 5 \times 4)$ observations. Each farmer had 5 choices from choice sets containing 4 options. Of the 328 questionnaires completed one had incomplete information and hence was dropped. The estimation was conducted in STATA 13. To reduce simulation errors in parameter estimates, 100 Halton draws were used in the mixed logit estimation. For ease of analysis and interpretation of results the attribute 'multiple uses of water' was transformed into a dummy variable with 1 representing multiples uses of irrigation water and 0 otherwise.

After estimating the conditional logit model, a test for the IIA assumption using the Hausman-McFadden test was conducted. It compared the parameter estimates of the full model, which are consistent and efficient, to those of the restricted model that includes some of the outcomes (consistent and inefficient) (Cheng and Long, 2007). The test was estimated for each outcome of the dependent variable (alternative choices), which meant 4 tests were conducted. The significant test results in Table 4 meant that the IIA assumption did not hold and hence the mixed logit model was estimated. The log-likelihood, Bayesian information criterion (BIC), and Akaike information criterion (AIC) values also confirmed that the mixed logit, which allows heterogenous preferences, is the better model compared to the conditional logit.

Table 5 presents the results of the mixed logit models estimated with and without interaction terms. As indicated earlier, the dependent variable is the 'farmer's choice of irrigation water use options'. The results of the two are similar and the signs of the coefficients are as expected except for the 'membership to a water governing institution' attribute. The results suggest that the coefficient of the membership attribute does not statistically significantly affect choices. The other three attributes have a significant impact on choices. The negative coefficient of the attribute 'water fees' shows that higher fees reduce the probability of a farmer selecting an expensive option. Both the 'number of crops per season' and 'multiple uses of irrigation water' positively influence the choice of an option. This means all farmer categories prefer the option of growing more crops and are willing to pay more for increased irrigation intensity. The results confirm findings from other studies that identified the importance of recognizing multiple uses of irrigation water (e.g., Meinzen-Dick and Van Der Hoek, 2001; Boelee et al., 2007) in water valuation. The negative sign of the ASC coefficient shows that farmers prefer the alternatives that offer different combinations of water services compared to the status quo. Only $20 \%$ of the farmers prefer the status quo situation.

The study tests the effect of gender differences on the WTP through an interaction term of water fees and gender. The results show a negative coefficient for the 'water fees $\times$ gender' interaction term, suggesting that being male negatively affects choices resulting in a lower WTP for irrigation water compared to females. Women farmers in the study community generally place a higher significance on crop farming compared to men, most of whom prefer the culturally valued livestock production. The SOFA Team and Doss (2011) drew similar conclusions for women in sub-Saharan Africa, and this could explain their higher WTP for irrigation water.

Table 4. Test for the IIA assumption

\begin{tabular}{lcc}
\hline Hausman-McFadden test & Chi-square & $p$-value \\
\hline Exclude Option 1 & 43.7 & 0.000 \\
Exclude Option 2 & 168.8 & 0.000 \\
Exclude Option 3 & 222.3 & 0.000 \\
Exclude Option 4 & 31.0 & 0.000
\end{tabular}

Table 3. Demographic and other characteristics of the sample farmers

\begin{tabular}{|c|c|c|c|c|c|c|c|c|}
\hline & $\begin{array}{l}\text { Scheme } \\
\text { irrigators } \\
(n=109)\end{array}$ & $\begin{array}{c}\text { Non- } \\
\text { scheme } \\
\text { irrigators } \\
(n=174)\end{array}$ & $\begin{array}{l}\text { Dryland } \\
\text { farmers } \\
(n=45)\end{array}$ & $P$-value & $\begin{array}{l}\text { Makhathini } \\
\quad(n=216)\end{array}$ & $\begin{array}{l}\text { Ndumo } \\
(n=112)\end{array}$ & $P$-value & $\begin{array}{c}\text { Total } \\
(N=328)\end{array}$ \\
\hline Gender (\% female) & 62.4 & 64.6 & 71.1 & 0.587 & 75.5 & 46.4 & 0.000 & 64.9 \\
\hline Age of farmer & $\begin{array}{l}47.6 \\
(1.2)\end{array}$ & $\begin{array}{l}49.2 \\
(0.9)\end{array}$ & $\begin{array}{c}50.2 \\
(1.8)\end{array}$ & 0.357 & $\begin{array}{l}49.1 \\
(12.6)\end{array}$ & $\begin{array}{l}48.4 \\
(10.7)\end{array}$ & 0.607 & $\begin{array}{l}48.8 \\
(0.66)\end{array}$ \\
\hline Number of years in formal school & $\begin{array}{l}4.8 \\
(0.4)\end{array}$ & $\begin{array}{l}4.1 \\
(0.4)\end{array}$ & $\begin{array}{c}3.8 \\
(0.7)\end{array}$ & 0.303 & $\begin{array}{l}43 \\
(4.5)\end{array}$ & $\begin{array}{c}4.3 \\
(4.6)\end{array}$ & 0.988 & $\begin{array}{c}4.3 \\
(0.3)\end{array}$ \\
\hline Number of crops & $\begin{array}{c}1.3 \\
(0.1)\end{array}$ & $\begin{array}{c}1.8 \\
(1.0)\end{array}$ & $\begin{array}{c}1.1 \\
(0.3)\end{array}$ & 0.000 & $\begin{array}{c}1.4 \\
(0.7)\end{array}$ & $\begin{array}{c}1.7 \\
(1.0)\end{array}$ & 0.001 & $\begin{array}{c}1.5 \\
(0.1)\end{array}$ \\
\hline Number of cattle & $\begin{array}{l}5.3 \\
(1.2)\end{array}$ & $\begin{array}{c}4.6 \\
(0.7)\end{array}$ & $\begin{array}{l}14.8 \\
(5.5)\end{array}$ & 0.001 & $\begin{array}{c}6.3 \\
(19.1)\end{array}$ & $\begin{array}{c}6.0 \\
(11.1)\end{array}$ & 0.875 & $\begin{array}{l}6.24 \\
(0.9)\end{array}$ \\
\hline Income from crops ( $\left.R^{\prime} 000\right)$ & $\begin{array}{l}15.3 \\
(5.2)\end{array}$ & $\begin{array}{c}7.5 \\
(1.3)\end{array}$ & $\begin{array}{l}5.4 \\
(1.4)\end{array}$ & 0.118 & $\begin{array}{l}4.9 \\
(0.6)\end{array}$ & $\begin{array}{l}19.2 \\
(5.3)\end{array}$ & 0.000 & $\begin{array}{c}9.8 \\
(1.9)\end{array}$ \\
\hline Membership in a cooperative (\% members) & 64.2 & 67.8 & 73.3 & 0.539 & 72.9 & 56.8 & 0.003 & 67.4 \\
\hline $\begin{array}{l}\text { Interested in being part of an institution } \\
\text { governing water (\% interested) }\end{array}$ & 59.0 & 68.2 & 66.7 & 0.069 & 64.6 & 65.7 & 0.293 & 65.0 \\
\hline \multicolumn{9}{|l|}{ Other uses of irrigation water: } \\
\hline Livestock watering (\%) & 55.6 & 80.6 & 70.5 & 0.000 & 62.8 & 86.9 & 0.000 & 70.8 \\
\hline Domestic use (\%) & 59.3 & 81.2 & 70.5 & 0.001 & 65.6 & 86.9 & 0.000 & 72.4 \\
\hline Construction (\%) & 52.8 & 78.2 & 68.2 & 0.000 & 61.4 & 82.2 & 0.000 & 68.3 \\
\hline
\end{tabular}

Note: Values in parentheses are standard errors 
Table 5. Estimation results for all farmers $(n=327)$

\begin{tabular}{|c|c|c|c|c|}
\hline \multirow{2}{*}{ Attributes } & \multicolumn{2}{|c|}{ MXL simple } & \multicolumn{2}{|c|}{ MXL with interactions } \\
\hline & Coef. & Std. Err. & Coef. & Std. Err. \\
\hline ASC & $-0.586^{\mathrm{a}}$ & 0.190 & $-0.554^{\mathrm{a}}$ & 0.190 \\
\hline Membership to water organization & -0.053 & 0.083 & -0.046 & 0.083 \\
\hline Number of crops & $0.354^{\mathrm{a}}$ & 0.062 & $0.358^{\mathrm{a}}$ & 0.063 \\
\hline Multiple uses & $1.098^{\mathrm{a}}$ & 0.216 & $0.959^{\mathrm{a}}$ & 0.224 \\
\hline Water fees & $-4.81 \times 10^{4 a}$ & $2.48 \times 10^{5}$ & $-4.34 \times 10^{4 a}$ & $2.97 \times 10^{5}$ \\
\hline Multiple uses $\times$ no. of cattle & & & $0.035^{\mathrm{b}}$ & 0.015 \\
\hline Water fees $\times$ gender & & & $-1.94 \times 10^{4 a}$ & $5.17 \times 10^{5}$ \\
\hline Water fees $\times$ crop income & & & $1.52 \times 10^{9}$ & $9.54 \times 10^{10}$ \\
\hline \multicolumn{5}{|l|}{ SD } \\
\hline Membership to water organization & 0.170 & 0.219 & 0.126 & 0.242 \\
\hline Number of crops & $0.712^{\mathrm{a}}$ & 0.074 & $0.733^{\mathrm{a}}$ & 0.075 \\
\hline Multiple uses & $2.763^{\mathrm{a}}$ & 0.210 & $2.686^{a}$ & 0.207 \\
\hline Number of observations & 6540 & & 6540 & \\
\hline $\operatorname{LR} \operatorname{chi}^{2}(4)$ & 541.7 & & 529.7 & \\
\hline Prob $>\mathrm{chi}^{2}$ & 0.000 & & 0.000 & \\
\hline Log likelihood & -1777.8 & & -1763.9 & \\
\hline AIC & 3571.6 & & 3549.8 & \\
\hline $\mathrm{BIC}$ & 3625.9 & & 3624.5 & \\
\hline
\end{tabular}

Note: $a, b, c$ significant at the $1 \%, 5 \%$ and $10 \%$, respectively; SD - standard deviations

The study also tests the hypothesis that higher crop income increases farmers' WTP for water using an interaction term between 'water fees' and 'crop income'. The results indicate that the potential for higher income earnings from crop production increases farmers' WTP. Thus, improving the productivity of agricultural enterprises and ensuring profitable markets for the marketable surplus will positively impact farmers' effective demand and hence their WTP for irrigation water. Similar results were also obtained in a study conducted in China where income had a positive and significant effect on WTP for irrigation water (Tang et al., 2013). The coefficient of the interaction term between cattle ownership and the 'multiple uses of irrigation water' attribute is statistically significant and positive. This shows that farmers with larger stocks of cattle have a higher probability of choosing the multiple uses attribute and are willing to pay more for water. These farmers are typically benefiting from the complementarity of crop-livestock integration. Other studies confirm these findings and show that on-farm irrigation water has value in livestock watering and feed production (Hewitt, 2013; FAO, 2018).

The standard deviations of the 'number of crops per season' and 'multiple uses of irrigation water' attributes are statistically significant $(p<0.01)$, showing heterogeneity in farmers' preferences for these attributes. The magnitudes of the mean and standard deviation show further information on the proportion of smallholders with a negative or positive preference of an attribute. Following Hole (2007), the proportions are given by $100 \times \Phi\left(-b_{x} / s_{x}\right)$, where $b_{x}$ and $s_{x}$ are the mean and standard deviation of the $x^{\text {th }}$ coefficient while $\Phi$ is the cumulative standard normal distribution function. The results show that $69 \%$ of the smallholders prefer to use irrigation water for many more purposes and $65 \%$ prefer to grow more than one crop. Adding interaction effects to the model has no significant effect on the proportion of farmers with such preferences.

\section{Preferences in managing irrigation water across farmer categories}

The results in Table 6 show heterogeneity in preferences between the different categories of farmers and the study areas. The coefficient of the attribute 'multiple uses of irrigation water' is positive but significant only for the scheme and non-scheme irrigators. However, the coefficient of the interaction term between the attribute 'multiple uses of irrigation water' and the 'number of cattle owned' is statistically significant only for dryland farmers. This means, due to the value that dryland farmers place on their livestock, multiple uses of irrigation water are important only as they relate to the livestock enterprise. Other studies have shown that livestock are an integral component of smallholder mixed cropping systems and the integration enhances income diversification, land productivity and water efficiency (Liniger et al., 2011; Mekuria and Mekonnen, 2018). The coefficient of the interaction term 'water fees $\times$ crop income' has a significant positive influence on choices and the WTP for non-scheme irrigators only. This suggests that higher income from crops will enhance the ability to pay for irrigation water among farmers irrigating outside of the schemes.

Regarding spatial differences, the cattle ownership effect on 'multiple uses of irrigation water', and hence choices is statistically significant for Makhathini and not Ndumo-B area. This suggests that integrating livestock with crop production will enhance smallholder ability to pay for irrigation water in Makhathini. The impact of gender and crop income on 'water fees' and hence the ability to pay for irrigation water is statistically significant for Ndumo-B and not Makhathini. This means female smallholders in Ndumo-B are more price sensitive compared to men and have a lower WTP. Despite women valuing smallholder agriculture more than men, other factors make those in Ndumo-B more economically vulnerable and hence could face challenges paying for irrigation water. Njoko and Mudhara (2017) found similar 
results that showed that in most parts of rural KwaZulu-Natal, men have a higher ability to pay for water compared to women. Sharaunga et al. (2016) report that women in South Africa are disproportionately economically disempowered compared to their male counterparts. The significance of the coefficient of 'water fees $\times$ crop income' interaction term for Ndumo-B shows that increased productivity and profitable markets for the marketable surplus will have more impact on smallholder WTP in this area and not Makhathini.

\section{Farmers' WTP for different attributes}

Table 7 presents the mean WTP for the different water-related services, estimated from the model with interaction effects. The negative WTP values show the lack of willingness to pay for that attribute. The bigger the number, the more unwilling are the farmers to pay for the attribute. The results suggest that farmers value the additional benefits derived from the use of irrigation water for other purposes more than the other attributes. 'Membership to a water governing institution' is the less valued of the three, for the reasons discussed earlier. The heterogeneity in preferences is observed through different WTP estimates for the attributes. Non-scheme irrigators are willing to pay ZAR1 213 more than what scheme irrigators are willing to pay for additional uses of irrigation water. This is because a higher proportion of non-scheme irrigators use irrigation water for other purposes compared to scheme irrigators (see Table 3). Similarly, for the same reasons, farmers in Ndumo-B are willing to pay more compared to Makhathini for the same attribute.

The results also suggest that farmers growing more crops (multiple and/or more of the same) are willing to pay extra for the use of more water, and the WTP is higher for scheme irrigators and Ndumo-B compared to other farmers. This finding suggests that irrigation water pricing should reflect irrigation intensity leading to efficient water allocation outcomes, an argument also put forward by Giraldo et al.
(2014). Although the initial cost might end up being prohibitive to resource-poor farmers (Abu-Zeid, 2001), volumetric water pricing remains the best option for improving efficient utilization of water in smallholder irrigation. However, in the absence of volumetric charging, enhancing irrigation design, such as having clearly defined and enforceable watersharing arrangements can result in efficient allocation of water resources (Ostrom et al., 1994). Despite facing frequent crop failures, the low dryland farmers' WTP values across all attributes is an indication of their negative valuation and perceptions of irrigation water payment compared to the other smallholders. Payment for water is a new phenomenon to such farmers, most of whom have never paid for water use before. Their attitudes to irrigation water payment are thus bound to be different from the rest of the farmers.

\section{CONCLUSION AND RECOMMENDATIONS}

Water valuation is an important step to address market failure in irrigation water and induce efficient utilization of the resource in the smallholder irrigation sector. Water scarcity threatens agricultural production and productivity and, therefore, endangers food security, employment and rural livelihoods. The study set to assess farmers' preferences in managing irrigation water resources and determine their WTP for irrigation water using the CEM approach. It contributes to the debate on irrigation water pricing for resource-poor farmers and improving efficient utilization of water resources. The farmers' WTP to produce more valuable crops implies that irrigation water use charges should reflect irrigation intensity. This will also contribute to curbing overirrigation which will continue to happen if water is underpriced. It is recommended that the water pricing policy shifts from the current average charge per hectare to a volumetric charging system at the farmer level. The government should fund the initial meter installation costs with a cost recovery

Table 6. Mixed logit estimation results for different farmer categories and study areas

\begin{tabular}{|c|c|c|c|c|c|c|c|c|c|c|}
\hline \multirow{2}{*}{ Attributes } & \multicolumn{2}{|c|}{ Scheme irrigators } & \multicolumn{2}{|c|}{ Non-scheme irrigators } & \multicolumn{2}{|c|}{ Dryland farmers } & \multicolumn{2}{|c|}{ Makhathini } & \multicolumn{2}{|c|}{ Ndumo-B } \\
\hline & Coef. & Std. Err. & Coef. & Std. Err. & Coef. & Std. Err. & Coef. & Std. Err. & Coef. & Std. Err. \\
\hline $\begin{array}{l}\text { Membership to } \\
\text { water organization }\end{array}$ & -0.216 & 0.152 & 0.088 & 0.116 & -0.121 & 0.275 & -0.104 & 0.102 & 0.028 & 0.155 \\
\hline Number of crops & $0.365^{\mathrm{a}}$ & 0.121 & $0.349^{\mathrm{a}}$ & 0.080 & $0.321^{c}$ & 0.195 & $0.165^{b}$ & 0.081 & $0.741^{\mathrm{a}}$ & 0.104 \\
\hline Multiple uses & $0.657^{c}$ & 0.404 & $1.339^{\mathrm{a}}$ & 0.317 & 0.684 & 0.660 & $0.662^{b}$ & 0.292 & $1.693^{\mathrm{a}}$ & 0.401 \\
\hline Water fees & $-3.21 \times 10^{4 a}$ & $5.10 \times 10^{5}$ & $-0.001^{\mathrm{a}}$ & $4.33 \times 10^{5}$ & $-3.80 \times 10^{4 a}$ & $7.86 \times 10^{5}$ & $-3.72 \times 10^{4 a}$ & $3.60 \times 10^{5}$ & $-0.001^{\mathrm{a}}$ & $6.53 \times 10^{5}$ \\
\hline $\begin{array}{l}\text { Multiple uses } \times \text { no. } \\
\text { of cattle }\end{array}$ & 0.037 & 0.027 & 0.041 & 0.026 & $0.037^{c}$ & 0.020 & $0.027^{b}$ & 0.013 & 0.035 & 0.023 \\
\hline Water fees $\times$ gender & $-1.85 \times 10^{4 b}$ & $8.91 \times 10^{5}$ & $-1.61 \times 10^{4 b}$ & $7.11 \times 10^{5}$ & $-0.001^{a}$ & $2.13 \times 10^{4}$ & $-3.91 \times 10^{5}$ & $6.20 \times 10^{5}$ & $-2.86 \times 10^{4 a}$ & $9.29 \times 10^{5}$ \\
\hline $\begin{array}{l}\text { Water fees } \times \text { crop } \\
\text { income }\end{array}$ & $9.44 \times 10^{10}$ & $1.23 \times 10^{9}$ & $5.27 \times 10^{9 a}$ & $1.81 \times 10^{9}$ & $-5.92 \times 10^{8}$ & $4.26 \times 10^{8}$ & $-1.95 \times 10^{9}$ & $3.06 \times 10^{9}$ & $2.45 \times 10^{9 b}$ & $1.17 \times 10^{9}$ \\
\hline ASC & -0.410 & 0.312 & $-0.565^{b}$ & 0.268 & -0.695 & 0.554 & $-0.802^{\mathrm{a}}$ & 0.232 & 0.181 & 0.354 \\
\hline \multicolumn{11}{|l|}{ SD } \\
\hline $\begin{array}{l}\text { Membership to } \\
\text { water organization }\end{array}$ & -0.460 & 0.353 & -0.040 & 0.244 & -0.557 & 0.527 & -0.234 & 0.384 & -0.049 & 0.269 \\
\hline Number of crops & $0.898^{\mathrm{a}}$ & 0.149 & $0.596^{\mathrm{a}}$ & 0.092 & $0.854^{\mathrm{a}}$ & 0.240 & $0.789^{a}$ & 0.098 & $0.560^{\mathrm{a}}$ & 0.120 \\
\hline Multiple uses & $2.673^{\mathrm{a}}$ & 0.364 & $2.598^{\mathrm{a}}$ & 0.267 & $-3.119^{a}$ & 0.640 & $-3.201^{\mathrm{a}}$ & 0.312 & $2.092^{\mathrm{a}}$ & 0.304 \\
\hline $\begin{array}{l}\text { Number of } \\
\text { observations }\end{array}$ & 2180 & & 3460 & & 900 & & 4300 & & 2240 & \\
\hline $\operatorname{LR~chi²}(4)$ & 213.0 & & 225.5 & & 88.0 & & 447.5 & & 80.6 & \\
\hline Prob $>\mathrm{chi}^{2}$ & 0.000 & & 0.000 & & 0.000 & & 0.000 & & 0.000 & \\
\hline Log likelihood & -600.3 & & -916.8 & & -219.9 & & -1172.1 & & -553.0 & \\
\hline
\end{tabular}

Note: ${ }^{a, b, c}$ significant at the $1 \%, 5 \%$ and $10 \%$ levels, respectively; SD- standard deviations 
Table 7. Mean WTP for water estimates

\begin{tabular}{|c|c|c|c|c|c|c|}
\hline \multirow[b]{2}{*}{ Attribute } & \multicolumn{6}{|c|}{ Mean WTP } \\
\hline & $\begin{array}{l}\text { Pooled } \\
\text { sample }\end{array}$ & $\begin{array}{c}\text { Scheme } \\
\text { irrigators }\end{array}$ & $\begin{array}{c}\text { Non-scheme } \\
\text { irrigators }\end{array}$ & $\begin{array}{l}\text { Dryland } \\
\text { farmers }\end{array}$ & Makhathini & Ndumo-B \\
\hline $\begin{array}{l}\text { Membership to water } \\
\text { organization }\end{array}$ & $\begin{array}{l}-145.3 \\
(199.8)\end{array}$ & $\begin{array}{r}-854.7 \\
(910.0)\end{array}$ & $\begin{array}{l}250 \\
(56.8)\end{array}$ & $\begin{array}{l}-217.3 \\
(499.1)\end{array}$ & $\begin{array}{r}-504.5 \\
(569.9)\end{array}$ & $\begin{array}{c}62.5 \\
(55.9)\end{array}$ \\
\hline Number of crops per season & $\begin{array}{r}569.8 \\
(1165.7)\end{array}$ & $\begin{array}{c}722.1 \\
(1775.1)\end{array}$ & $\begin{array}{c}497.8 \\
(851.3)\end{array}$ & $\begin{array}{c}287.2 \\
(764.6)\end{array}$ & $\begin{array}{c}401.6 \\
(1919.7)\end{array}$ & $\begin{array}{c}836.9 \\
(631.9)\end{array}$ \\
\hline Multiple uses of water & $\begin{array}{c}3108.1 \\
(4274.3)\end{array}$ & $\begin{array}{c}2671.0 \\
(5286.3)\end{array}$ & $\begin{array}{l}3884.0 \\
(3710.5)\end{array}$ & $\begin{array}{c}1259.7 \\
(2793.7)\end{array}$ & $\begin{array}{l}3288.1 \\
(7791.2)\end{array}$ & $\begin{array}{c}3863.3 \\
(2362.5)\end{array}$ \\
\hline
\end{tabular}

Note: Estimates in South African Rand; figures in parenthesis () are standard deviations of mean WTP

strategy so that farmers can contribute towards this cost over time. To control the use of irrigation water, the design of farmer-managed irrigation systems should include clearly defined collective use arrangements with enforceable rules and mechanisms for conflict resolution. More WTP for additional uses of irrigation water confirms why it is important to consider multiple uses of irrigation water for efficient allocation and improved water management. Ignoring this value results in the undervaluation and unsustainable utilization of the resource. More importantly, the design and management of irrigation water infrastructure (such as canals) should integrate these other uses like livestock watering. This will reduce the damage to the irrigation infrastructure and avoid unnecessary water losses.

The study demonstrates how improving agricultural production and productivity with market access will improve farmers' willingness and ability to pay for irrigation water. Thus, there is a need to support policies and programmes (such as Agri-parks) that enhance the profitability of smallholder irrigation. This will positively impact farmers' contribution towards operation and maintenance costs for the schemes. The study also reiterates the importance of smallholder agriculture to women. Supporting women farmers has positive implications for efficient and sustainable utilization of irrigation water. Policies should seek to address existing gender gaps in accessing resources. Regarding dryland farmers, more awareness creation on water scarcity and the importance of efficient and sustainable utilization of water is required.

The study only focused on two irrigation schemes and hence studies in the future should expand this research nationally and regionally. A more difficult question for future research regarding irrigation water pricing concerns the possibility of integrating other irrigation water uses into the water pricing system. Proper cost-benefit analysis on the volumetric water charging at farmer level in the schemes should also be conducted. This will assist policy makers in planning for a smooth shift in the water pricing strategy.

\section{ACKNOWLEDGEMENTS}

The study was undertaken as part of a project (K5/2278/4) funded by the Water Research Commission (WRC). The final project report can be accessed via www.wrc.org.za as 'Appropriate entrepreneurial development paths for homestead food gardening and smallholder irrigation crop farming in KwaZulu-Natal Province (WRC Report No. 2278/1/18)'. The first author would like to acknowledge the WRC for financial support of his PhD study through this project. Special mention goes to the enumerators who worked hard during the data collection.

\section{REFERENCES}

ABU-ZEID M (2001) Water pricing in irrigated agriculture. Int. J. Water Resour. Dev. 17 (4) 527-538.

ASRAT S, YESUF M, CARLSSON F and WALE E (2010) Farmers' preferences for crop variety traits: Lessons for on-farm conservation and technology adoption. Ecol. Econ. 69 (12) $2394-$ 2401. https://doi.org/10.1016/j.ecolecon.2010.07.006

BACKEBERG GR (2006) Reform of user charges, market pricing and management of water: problem or opportunity for irrigated agriculture? Irrig. Drain. 55 (1) 1-12. https://doi.org/10.1002/ ird. 221

BARTON DN and BERGLAND O (2010) Valuing irrigation water using a choice experiment: an 'individual status quo' modelling of farm specific water scarcity. Environ. Dev. Econ. 15 (3) 321-340. https://doi.org/10.1017/s1355770x10000045

BARTON DN and TARON A (2010) Valuing irrigation water using survey-based methods in the Tungabhadra River Basin, India. Irrig. Drain. Syst. 24 (3-4) 265-277. https://doi.org/10.1007/ s10795-010-9098-2

BECH M and GYRD-HANSEN D (2005) Effects coding in discrete choice experiments. Health Econ. 14 (10) 1079-1083. https://doi. org/10.1002/hec.984

BHADURI A and KLOOS J (2013) Getting the water prices right using an incentive-based approach: an application of a choice experiment in Khorezm, Uzbekistan. Eur. J. Dev. Res. 25 (5) 680-694. https:// doi.org/10.1057/ejdr.2013.30

BIROL E, KAROUSAKIS K and KOUNDOURI P (2006) Using economic valuation techniques to inform water resources management: a survey and critical appraisal of available techniques and an application. Sci. Total Environ. 365 105-122. https://doi. org/10.1016/j.scitotenv.2006.02.032

BOELEE E, LAAMRANI H and VAN DER HOEK W (2007) Multiple use of irrigation water for improved health in dry regions of Africa and South Asia. Irrig. Drain. 56 (1) 43-51. https://doi.org/10.1002/ ird. 287

CHENG S AND LONG JS (2007) Testing for IIA in the multinomial logit model. Sociol. Meth. Res. 35 (4) 583-600.

DWS (Department of Water and Sanitation, South Africa) (2015) Draft pricing strategy for water use charges. Department of Water and Sanitation, Pretoria.

FAO (2011) The state of the world's land and water resources for food and agriculture - managing systems at risk.

FAO (2018) Water use of livestock production systems and supply chains - Guidelines for assessment (Draft for public review). Livestock Environmental Assessment and Performance (LEAP) Partnership. FAO, Rome.

GIERGICZNY M, VALASIUK S, CZAJKOWSKI M, DE SALVO M and SIGNORELLO G (2012) Including cost income ratio into utility function as a way of dealing with 'exploding'implicit prices in mixed logit models. J. For. Econ. 18 (4) 370-380. https://doi. org/10.1016/j.jfe.2012.07.002

GIRALDO L, CORTIGNANI R and DONO G (2014) Simulating volumetric pricing for irrigation water operational cost recovery under complete and perfect information. Water 6 (5) 1204-1220. https://doi.org/10.3390/w6051204 
GREENE WH (2012) Econometric Analysis. (7 $7^{\text {th }}$ edn). Pearson Education Limited, London.

HAUSMAN J and MCFADDEN D (1984) Specification tests for the multinomial logit model. Econometrica 1219-1240. https://doi. org/10.2307/1910997

HEWITT K (2013) Water efficiency usage in agriculture: Evaluating the use of allocated water in food production. Undergraduate Honours thesis, University of Colorado.

HOLE AR (2007) Estimating mixed logit models using maximum simulated likelihood. Stata J. 7 (3) 388-401. https://doi. org/10.1177/1536867x0700700306

JAECK M AND LIFRAN R (2009) Preferences, norms and constraints in farmers' agro-ecological choices: case study using a choice experiments survey in the Rhone River Delta, France. Paper presented at: AARES 2009 Conference, Cairns, 11-13 February 2009.

JOHNSON FR, LANCSAR E, MARSHALL D, KILAMBI V, MÜHLBACHER A, REGIER DA, BRESNAHAN BW, KANNINEN $B$ and BRIDGES JF (2013) Constructing experimental designs for discrete-choice experiments: report of the ISPOR conjoint analysis experimental design good research practices task force. Value in Health 16 (1) 3-13. https://doi.org/10.1016/j.jval.2012.08.2223

JOZINI LOCAL MUNICIPALITY (2015) Jozini integrated development plan 2015/16. uMkhanyakhude District, KwaZulu-Natal.

KANYOKA P, FAROLFI S and MORARDET S (2008) Households' preferences and willingness to pay for multiple use water services in rural areas of South Africa: an analysis based on choice modelling. Water SA 34 (6) 715-723.

KRUGER AC and NXUMALO MP (2017) Historical rainfall trends in South Africa: 1921-2015. Water SA 43 (2) 285-297. https://doi. org/10.4314/wsa.v43i2.12

KUHFELD WF (2010) Marketing Research Methods in SAS. SAS 9.2. SAS Institute, NC, USA.

KUNIMITSU Y (2009) Measuring the implicit value of paddy irrigation water: application of RPML model to the contingent choice experiment data in Japan. Paddy Water Environ. 7 (3) 177-185. https://doi.org/10.1007/s10333-009-0159-9

LANCASTER KJ (1966) A new approach to consumer theory. J. Polit. Econ. 74 (2) 132-157.

LANGE G and HASSAN R (2007) The Economics of Water Management in Southern Africa: An Environmental Accounting Approach. Edward Elgar, Cheltenham, UK.

LAYTON DF (2000) Random coefficient models for stated preference surveys. J. Environ. Econ. Manag. 40 (1) 21-36.

LEE D, HOSKING S and DU PREEZ M (2014) A choice experiment application to estimate willingness to pay for controlling excessive recreational fishing demand at the Sundays River Estuary, South Africa. Water SA 40 (1) 39-40. https://doi.org/10.4314/wsa.v40i1.5

LINIGER H, MEKDASCHI SR, HAUERT C AND GURTNER M (2011) Sustainable land management in practice: guidelines and best practices for Sub-Saharan Africa: field application. Rome: FAO.

MANGHAM LJ, HANSON K and MCPAKE B (2009) How to do (or not to do). Designing a discrete choice experiment for application in a low-income country. Health Polic. Plann. 24 (2) 151-158. https://doi.org/10.1093/heapol/czn047

MCFADDEN D (1973) Conditional logit analysis of qualitative choice behavior. In: Zarembka P (ed.) Frontiers in Economics. Academic Press, New York.

MEINZEN-DICK RS and VAN DER HOEK W (2001) Multiple uses of water in irrigated areas. Irrig. Drain. Syst. 15 (2) 93-98.

MEKURIA W and MEKONNEN K (2018) Determinants of crop-livestock diversification in the mixed farming systems: evidence from central highlands of Ethiopia. Agric. Food Security 7 (1) 1-15. https://doi.org/10.1186/s40066-018-0212-2

MUCHARA B, ORTMANN G, MUDHARA M and WALE E (2016) Irrigation water value for potato farmers in the Mooi River irrigation scheme of KwaZulu-Natal, South Africa: a residual value approach. Agric. Water Manage. 164 243-252. https://doi. org/10.1016/j.agwat.2015.10.022

MUCHARA B, WALE E, ORTMANN GF and MUDHARA M (2014) Collective action and participation in irrigation water management: a case study of Mooi River irrigation scheme in KwaZulu-Natal Province, South Africa. Water SA 40 (4) 699-708. https://doi.org/10.4314/wsa.v40i4.15

NJOKO S AND MUDHARA M (2017) Determinant of farmers' ability to pay for improved irrigation water supply in rural KwaZulu-Natal, South Africa. Water SA 43 (2) 229-237. https://doi. org/10.4314/wsa.v43i2.07

OSTROM E, LAM WF and LEE M (1994) The performance of selfgoverning irrigation systems in Nepal. Hum. Syst. Manage. 13 (3) 197-207.

RAY I (2011) Farm-level incentives for irrigation efficiency: some lessons from an Indian canal. J. Contemp. Water Res. Educ. 121 (1) 64-71.

REINDERS FB, STOEP I and BACKEBERG GR (2013) Improved efficiency of irrigation water use: a South African framework. Irrig Drain. 62 (3) 262-272. https://doi.org/10.1002/ird.1742

RSA (Republic of South Africa) (1998) National Water Act. Act No. 36 of 1998. Government Gazette 19182. Government Printer, Cape Town.

RYAN M, KOLSTAD J, ROCKERS P and DOLEA C (2012) How to conduct a discrete choice experiment for health workforce recruitment and retention in remote and rural areas: a user guide with case studies. World Health Organization \& Capacity Plus: World Bank. https://doi.org/10.2471/blt.09.068494

SCARPA R, THIENE M and TRAIN K (2008) Utility in willingness to pay space: a tool to address confounding random scale effects in destination choice to the Alps. Am. J. Agric. Econ. 90 (4) 994-1010. https://doi.org/10.1111/j.1467-8276.2008.01155.x

SCHREINER B (2015) Water pricing: the case of South Africa. In: Dinar A, Pochat V and Albiac-Murillo J (eds.) Water Pricing Experiences and Innovations. Springer International Publishing, Cham. https://doi.org/10.1007/978-3-319-16465-6_1

SCHUR M (2000) Pricing of irrigation water in South Africa, country report. World Bank, Washington DC.

SHARAUNGA S, MUDHARA M and BOGALE A (2016) Effects of 'women empowerment' on household food security in rural KwaZulu-Natal province. Dev. Polic. Rev. 34 (2) 223-252. https:// doi.org/10.1111/dpr.12151

SOFA TEAM and DOSS C (2011) The role of women in agriculture. FAO, Rome.

SPEELMAN S, FRIJA A, PERRET S, D'HAESE M, FAROLFI S and D'HAESE L (2011) Variability in smallholders' irrigation water values: study in North-West Province, South Africa. Irrig. Drain. 60 (1) 11-19. https://doi.org/10.1002/ird.539

TANG Z, NAN Z and LIU J (2013) The willingness to pay for irrigation water: a case study in Northwest China. Glob. Nest J. 15 (1) 76-84.

TRAIN K (2009) Discrete Choice Methods with Simulation. Cambridge University Press, Cambridge, New York.

YOUNG RA and LOOMIS JB (2014) Determining the Economic Value of Water: Concepts and Methods. (2nd edn). RFF Press, Routledge, New York, USA. 